\title{
Forestry in British Columbia: Planning for future climate today ${ }^{1}$
}

\author{
by D.F.W. Pollard ${ }^{2}$
}

\section{Introduction}

It is an honour to represent Forestry Canada at this celebration of UBC's 75th anniversary. As a forest scientist, I feel particularly privileged to be here. My education did not include studies at this great university. This means, of course, that I did not experience the teachings of one of Canada's foremost forest scientists, Vladimir Krajina. It was Professor Krajina's inspiration and labours that led to the development of this province's biogeoclimatic land classification system.

In 1975, the British Columbia Ministry of Forests adopted the system as a framework for classifying the many ecosystems of the province. For the first time, British Columbia had a planning tool for natural resource management that took account of a daunting array of climates, landforms and vegetation. It has become a cornerstone of forest management, and every self-respecting forester in British Columbia has a working knowledge of the system. Forestry practice considers the biogeoclimatic setting of a site at each stage of its development, from choice of planting stock to post-harvesting prescriptions. This great leap forward in site specific management is probably the greatest asset we have as we set and reset our management objectives for one of the world's truly great forest resources.

Undoubtedly, the province is managing its forest on a very solid ecological base. But management decisions must make an important assumption. They must assume that biogeoclimatic zones are stable. They assume that when a seedling is matched to a particular seed-zone, the seed-zone will stay in place and not move over the next 70 years. When we plant today, we plan for tomorrow. In particular, we plan for tomorrow's climate. I'll quote from the Ministry's own version of the system, published in 1988 (British Columbia 1988a):

"In the biogeoclimatic system, climate is considered to be the most important environmental factor influencing ecosystem development",

And we all know - or at least we are told - that the climate will change significantly in the next 70 years.

Now the worst thing we can do in the face of uncertainty is to instil panic. Trees and forests are very resilient. We have trees in Canada that have survived many centuries of changing climate, and they are not confined to coastal British Columbia. From time to time, however, we are reminded that the forest sector is sensitive to climate. Let me illustrate with a couple of examples.

\footnotetext{
${ }^{1}$ Invited lecture, University of British Columbia 1915-1990 Anniversary Conference, Global environmental change: the implications for British Columbia, Coast Plaza Hotel, Vancouver, B.C., September 24-26, 1990. ${ }^{2}$ Research Scientist, Forestry Canada, Pacific Forestry Centre, Victoria, B.C., V8Z 1 M5
}

One of Canada's lesser known forest products is seed. For many years, Canada has been northern Europe's gene pool. The richest sources by far have been B.C. and the Yukon. Collectors in this province export perhaps a million dollars worth of seed each year. The most important species is lodgepole pine, being favoured by Swedish foresters as a useful alternative to their own Scots pine. Almost half a million hectares have been planted with this species in northern Sweden.

Recently, Swedish scientists have observed a rapid increase in the extent of a fungal disease, Gremmeniella, in young plantations (Karlman 1990). News reached the Swedish Board of Forestry, who immediately restricted further planting of lodgepole pine. Last year, Canadian exports of lodgepole pine seed dropped by $80 \%$.

Now this is not a case of infected seed. The disease is indigenous to Sweden, and is affecting local Scots pine also. The problem is one of climatic variability. In 1986, northern Sweden experienced a mild winter with exceptionally heavy snow. This followed several years with cold wet summers, very cold winters and highly variable temperatures in late fall and spring. Young trees, bowed over with wet snow, offered ideal conditions for development of the disease. With a return to more normal winters, trees will recover, but aspersions cast on lodgepole pine as an exotic species will stick, with repercussions for seed collectors in western Canada. Climatic variability, of even very remote places, can and does affect our forest sector.

Ten years ago, the Ministry of Forests was publishing a delightful magazine called Forestalk. In one of its last issues, Doug Cowell, a freelance writer in Vancouver, wrote an article on winter logging in B.C. (Cowell 1981). Many of you will recall that 1980 was a notably mild winter in much of the northern hemisphere. Now everyone loves a mild winter. People migrate to British Columbia for its mild winters. But mild winters have their problems for foresters in northern, Canada who depend on having frigid conditions of -30 to $-40^{\circ} \mathrm{C}$ for several weeks. In 1980 , forest operations were repeatedly shut down in the Prince George area, as a result of intractable conditions developing at landings, and as inadequately frozen roads disintegrated. A thaw in late December led to premature ice breakup, flooding out several logging camps. We were reminded that we adapt our activities to the prevailing climate, however harsh or extreme it appears to be. Today's forestry is adapted to today's climate, and even now, extremes in its variability can be disruptive.

These extremes can give us clues to how future climates may affect our forest sector. Before we plunge into the speculative world of climate change, however, we might reflect for a moment on the remarks made a few years ago by Gerry Burch in his Burgess-Lane lecture to the Faculty of Forestry here at UBC (Burch 1987). Gerry, a former vicepresident of BC Forest Products Limited, reflected on the 
changing contexts of forestry over his 40 years in the industry. From the 1950 's to the 1980 's, the forest harvest in B.C. rose from 30 million to 80 million cubic meters. Annual seedling production rose from 7 million to 200 million. And as Gerry pointed out, the price of a cup of coffee rose from a dime to a dollar. He characterized the four decades thus:

for the 1950's, protection,

for the 1960's, utilization,

for the 1970's reforestation,

and for the 1980's, silviculture.

So what will the 1990's be? Your guess is as good as mine, and chances are high that we will both say "environment". But let us remember that social, political, economic and technological changes have had impacts on forestry as great as any we can reasonably expect from the projected changes in our global environment. Given the uncertainties of the future, we can only speculate intelligently, and advocate measures that address the uncertainty rather than the projection.

Despite such caveats, we are obliged to recognize that climate change is already an issue for forestry. The forest sector is steward of a vast pool of carbon, whose size and condition are sensitive to management policies. This point has gained an inordinate amount of attention lately, as the public perceives the link between forests and the atmosphere, and how it may be affected by commercial forestry.

Furthermore, forestry has the longest planning timeframe of any sector. This year, British Columbia planted almost 300 million seedlings that will experience climates of the year 2050 and beyond.

Everyone talks about sustainable development these days. But what is meant by sustainable development in a changing climate? What is to be sustained and what are the benchmarks for gauging our actions? Whether it is public pressure to preserve carbon reserves now, or greater hazards for our forests in warmer, drier climates of the future, the issue is one of sustainability of the sector.

In the remaining time, I shall discuss in some detail the linkages between the forest resource and the atmosphere, and how they may be affected by commercial forestry in British Columbia. I shall comment briefly on the impacts that climate change may have on the sector. By way of conclusion, I shall venture some ideas on basic elements of adaptive strategy to ensure sustainability.



Figure 1. The forest sector is steward of a vast pool of carbon.

\section{Perceptions of the Forest as a Carbon Pool}

The forest sector in British Columbia is already under pressure to preserve carbon pools. This is happening before the facts are in on climate change. The public may or may not be correct in its assumptions and tactics. Canada, after all, holds $10 \%$ of the world's forests in trust. About $40 \%$ of Canada's living biomass occurs here in British Columbia (Bonnor 1985), and there are massive concentrations in coastal areas.

In principle, and I do stress in principle, the conversion of cool temperate old growth to managed stands has one result in common with the destruction of tropical forests: it reduces stored carbon when pools are averaged over time and space. In a now widely quoted paper in Science, Harmon and colleagues suggested that conversion of 5 million hectares of old growth to managed stands in Oregon and Washington could account for up to 1.8 billion tonnes of carbon released into the atmosphere over the past 100 years (Harmon et al. 1990). The accelerated decay of detritus was a major source of carbon dioxide in this process.

There are permanent changes in the living biomass to be considered also. Charles Cooper of San Diego has shown that a forest managed for maximum sustained yield has a mean lifetime carbon storage of about one-third that attained at maturity (Cooper 1983). Thus, even if the managed forest attains a biomass approximating that of the original old growth, there is still a net release of carbon following conversion.

A recent report commissioned by the BC Ministry of Energy, Mines and Petroleum Resources has attracted considerable attention because it identified the forest sector as the major producer of carbon dioxide in the province (Levelton 1990). The two largest sources of carbon dioxide were identified as the processing of pulp and paper, and the practice of prescribed burning. Together they reportedly accounted for 9 million tonnes of carbon, or $40 \%$ of the anthropogenic emissions for British Columbia for the year 1988. And so the obvious question is being asked, what is the forest sector doing about its carbon budget?

The picture may not be as serious as is portrayed by such figures. What constitutes a net release of carbon dioxide to the atmosphere is open to interpretation; for in forestry, what goes up can come down. The use of pulp wastes for energy

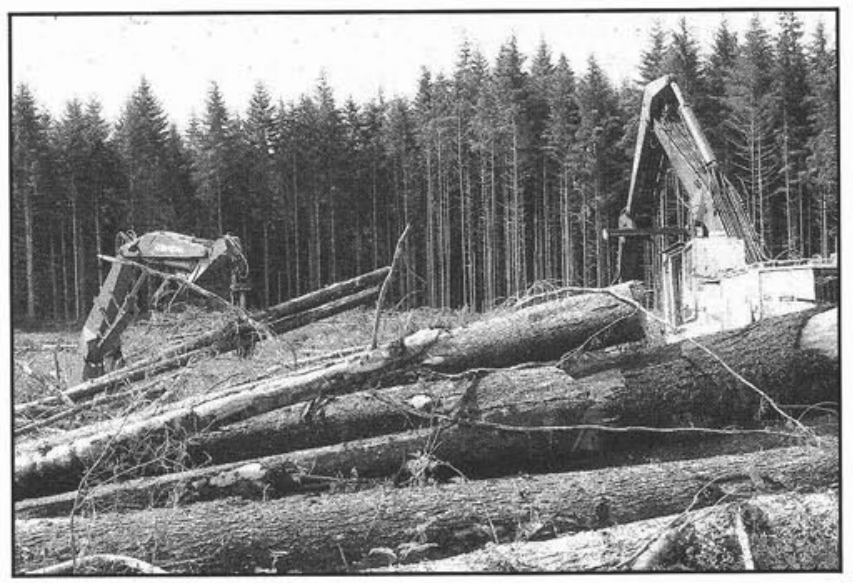

Figure 2. A recent report identified the forest sector as the major producer of carbon dioxide in the province. 


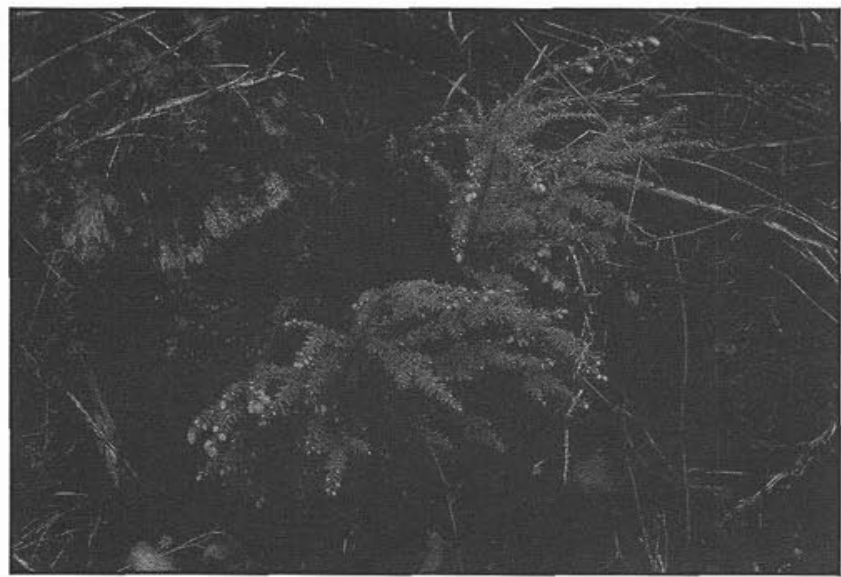

Figure 3. The burning of slash will be at least partially compensated by regrowth in the forest.

can be viewed as a displacement of fossil fuel by a renewable energy source. The burning of slash will be at least partially compensated by regrowth of the forest. Nevertheless, word is out that forestry is the major culprit, and this is affecting policy in the corporate boardrooms. At least two companies have already undertaken a carbon budget analysis of their operations.

If we are to take carbon budgets seriously, it is imperative that we identify where the main fluxes are, and how they are generated. Forestry Canada is supporting development of a simulation model of the carbon pools and fluxes in the Canadian forest sector, under the ENFOR or Energy from the Forest program. A Vancouver team, lead by Werner Kurz, has constructed the model (Kurz et al. in press). It integrates all significant elements of the sector, including live and detrital carbon pools, growth, predation, combustion, decay, and the fate of forest products. A sub-model addressing fossil fuel and other energy requirements in silviculture, harvesting and processing is also under development.

The model is incomplete, but it already confirms quite clearly that the major carbon pool of Canada is the boreal forest, with its highly organic soils. Moreover, the major source of carbon dioxide is the combustion of biomass and soil organic matter, occuring in the boreal forest, the subarctic, and in the cordilleran. Clearcutting and slashburning appear to be significant elements of the total carbon released from Canada's forests. However, the model also indicates that only in the sub-arctic does forest growth fail to compensate for fire losses.

There has been a modest accumulation of carbon in forest products over the past 40 years. But we do not have a good handle on their fate once they reach their destination. We know that landfill waste contains up to $70 \%$ wood products. The carbon balance model has been forced to make certain assumptions about the longevity of each type of product. However, this may prove to be insignificant compared with the fluxes incurred in forest ecosystems as they respond to exploitation, management and environmental change.

On balance, most of Canada's forest regions, including our coastal forests, appear to be net accumulators of carbon at present. In fact, our preliminary national estimates, albeit very rough, indicate a net annual accumulation of carbon comparable in magnitude to Time magazine's estimate of
105.6 million tonnes for Canada's annual emission of carbon from fossil sources (Anon. 1989a).

What happened before we began to exploit our forests? Whatever the character of forests, from coastal rainforest to boreal mixedwoods, their carbon content should have remained steady when considered over time and space. This hypothesis is supported by observations elsewhere. Analyses of polar ice core samples (Neftel et al. 1985) are usually quoted to illustrate the dramatic rise in atmospheric carbon dioxide. But they also indicate that there was little or no yearto-year change in atmospheric carbon dioxide 200 years ago, in contrast to a current annual increase of 0.4 percent. This implies that the world's forests, when relatively undisturbed by exploitation, were in dynamic equilibrium with the atmosphere, even though wildfire was uncontrolled. That is, viewed globally, forests neither removed nor contributed carbon dioxide.

The prevalence of young, actively growing forests in B.C. and elsewhere in North America today supports the conclusion that our forests are currently net absorbers of carbon dioxide. There is some prospect that conversion of certain types of natural forests, notably the boreal forest, to managed stands may increase their live biomass, through genetic and silvicultural enhancement, and through protection. It has been estimated, for example, that the carbon content of the Finnish boreal forest can be increased by almost $50 \%$, or 273 million tonnes of carbon, over the next 50 years, through silviculture (Pelkonen 1990). This would be sufficient to compensate for 39 years of Finland's current fuel emissions. We might reasonably deduce, therefore, that not all conversions of natural forests to managed stands have the same implications of conversion of coastal old growth in the Pacific Northwest.

We hear a lot these days about planting trees to combat the "greenhouse effect". Toronto has a plan, so does the State of Victoria in Australia, and so does the President of the United States. The Intergovernmental Panel on Climate Change is considering a global plan entailing 12 million hectares of new forest each year (Anon. 1989b). Is the forest sector of this province to become concerned with storing carbon, or will growing wood remain the primary use of the forest?

Of course, this raises the question of whether wood production should remain the pre-eminent role of the forest.

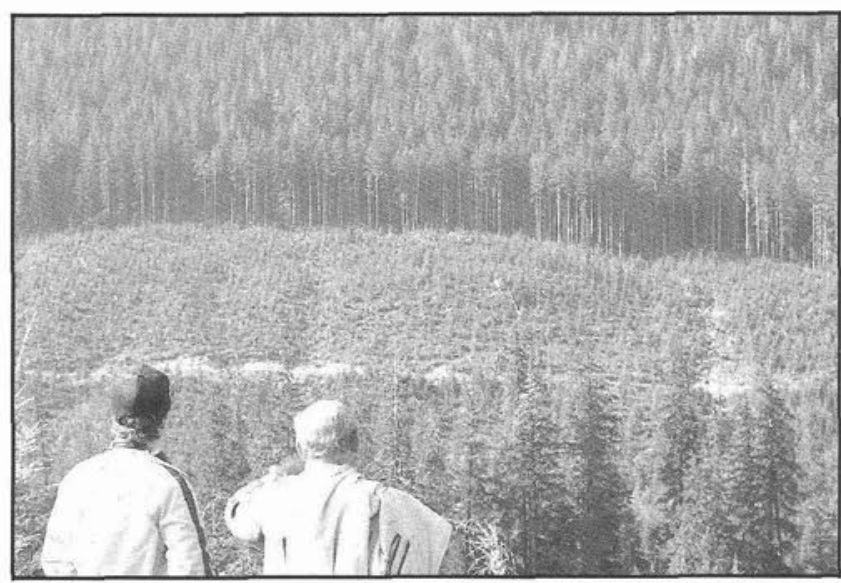

Figure 4. The prevalence of young, actively growing forest in B.C. and elsewhere in North America today supports the conclusion that our forests are currently net absorbers of carbon dioxide. 


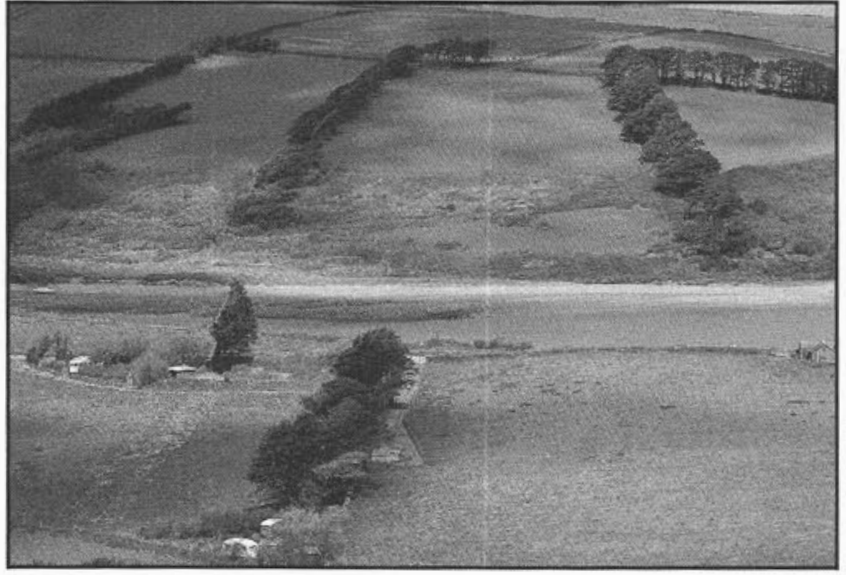

Figure 5. As a vivid example of what trees can do for us other than store carbon, consider the benefits of windbreaks.

Wildlife and other considerations have new values in today's society. It is not the moment to open up this particular controversy, but there is little doubt that climate change threatens impacts on all the many benefits we draw from forests. At the same time, I believe the current fad of planting for carbon storage should be challenged.

Can there be a less imaginative use of trees? Trees have wonderful aesthetic, environmental, physical and chemical qualities. To create a forest primarily to store carbon has to be a dismal reflection of our ability to get to grips with our problem, an admission that we cannot control our appetite for fossil fuels. A planting program must be focussed directly on the needs of people, for tomorrow and today.

As a vivid example of what trees can do for us other than store carbon, just consider the benefits of windbreaks: protection of livestock, increased crop yields, increased water catchment, living snowfences, improved aesthetics of the rural landscape, wildlife habitat, reductions in siltation, dust and noise, and reductions in heating and other energy needs (Brandle, in press). So where would you plant a million trees? Something to think about, even in British Columbia.

\section{Implications of a Change in Climate}

The opportunities for carbon sequestration by planting new forests are overshadowed by the possibility of major positive feedbacks from forest and other organic soils, especially in peatlands and areas currently subject to permafrost. A warming trend, amplified at northern latitudes, could well lead to very substantial emissions of methane and carbon dioxide from these vast areas. If such changes do indeed take place, the fate of disposible diapers in landfill will be utterly inconsequential.

The current arrangement of ecoclimatic provinces is very different from Environment Canada's concept of Canada under a scenario of doubled carbon dioxide (Rizzo 1988). The boreal forest, currently occupying $82 \%$ of Canada's forest land, would undergo massive fragmentation and northward movement of both its northern and southern boundaries. Less readily projected are the complex cordilleran regions of western Canada, where ocean, altitude and latitude interact to create an extremely complex landscape. These have not been modified in Environment Canada's projection. However, this is not an implied "no change". It is an admission that B.C. is too complex to be addressed in a quick, first approximation. The reason is obvious: there is as much variety in B.C. as there is in the rest of Canada put together. It is the very topic of Professor Krajina's pioneering work with B.C.'s land classification system.

As you might guess, we do not have a scenario for the biogeoclimatic system under a future climate, although Dave Spittlehouse of the Ministry of Forests is weighing the problem. Frankly, without it we cannot begin to assess the implications climate change has for the forest sector in this province. We can only speculate, and if forced to do so we should look first at the impacts on our tree species. The dominant physical presence of overstorey species creates and characterizes a unique series of microclimates and environments within and below the canopy. It is this diversity of environments, so very different from the one above the forest, that enables biodiversity to be expressed.

In considering future climate scenarios, Denis Lavender of UBC has expressed concern about the overwintering requirement for low temperature that controls the annual growth rhythm of Douglas-fir: it is possible that chilling requirements will cease to be met in coastal regions of Oregon and Washington (Kavender 1985). Other workers have concluded that Douglas-fir, western hemlock, and lodgepole pine would be affected by increasing summer moisture stress, but mainly in their southern and eastern ranges (Leverenz and Lev 1987). In Canada, they may be affected locally but there would not be severe losses in distribution. The same would not hold for Engelmann spruce, and by inference, white spruce. Under moisture stress, one of B.C.'s most important species could succumb to competition from lodgepole pine, or encounter increased snow pack or lack of soils at higher elevations.

Clearly, nothing can be said with certainty, except that carbon dioxide and other radiatively active gases are on the rise. We can only speculate on matters such as the impacts of milder winters on logging, of wetter winters on young lodgepole pine plantations, of hotter, drier summers on mountain pine beetle, or of a change in the incidence of fire (Pollard 1985). In a word, we are faced with uncertainty, and lots of it. As Ian Burton recently pointed out, it is very difficult to identify a satisfactory adaptive strategy in the face of uncertainty.

But perhaps we are asking too much of ourselves. Business decisions invariably are made in an atmosphere of

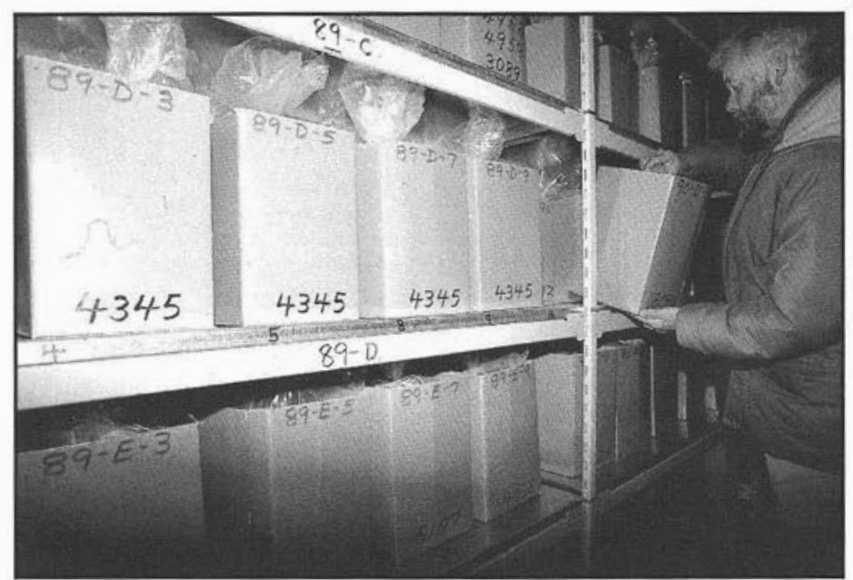

Figure 6. One of the benefits of our high-tech forest lies in our ability to collect, store and deploy vast quantities of seed. 
uncertainty. Interest and exchange rates, political structure and global security can all change by the week. Efforts to reduce uncertainty about one factor, climate, are exemplary compared with forecasts we see in certain business columns. And we may as well accept the advice of Tom Karl of the National Climate Data Centre, North Carolina, when he says that we should not expect an improvement in uncertainties over climate for at least 10 years (Karl, in press).

We should not expect foresters to sit still for the next 10 years and ignore the prospect of climate change. They are all too aware that they are planting, and therefore planning, for tomorrow's climate. They are going to push for information and guidance. What are we to suggest?

\section{Strategies for Adaptation}

The underlying theme of any advocacy ventured at present must be the uncertainty of the scenarios. Rather than state that our best guess is a $3.5^{\circ} \mathrm{C}$ warming over the next 50 years, we must stress that the future is extremely uncertain. Plans should be such that if warming does not occur, no irrevocable damage will be caused by adaptive tactics. It is definitely too soon to modify our planting programs or our protection infrastructure, or change our harvesting procedures. If climate does not change as expected, we shall have spent money needlessly, and worse, we may have seriously compromised our forests.

What we can advocate with confidence is flexibility. We are reminded repeatedly of how flexible the industrial side of the sector can be. For example, the sector can respond quickly to new opportunities in resource supply, by salvaging dead trees from pest infestations, utilizing formerly waste materials, reconstituting wood into quality products, and using the unusable, such as aspen.

I suggest we revisit John Harper's ideas on genetic resources, particularly as they apply to those all-important overstorey species (Harper 1990). This is where we can develop a low-cost strategy of defense that can benefit the sector whatever the future. It is an area where British Columbia has already established a fine track record, thanks to the leadership of people like Oscar Sziklai of UBC, a long standing program of the Ministry of Forests, and a continued commitment from industry.

Left to her own devices, nature would not be entirely helpless. There may well be sufficient adaptability in the gene pool of crop and other species to cope with the vagaries of even quite rapid climate change. Indeed, mature trees appear to withstand major departures from their climate of origin, as evidenced by exotic specimens in arboreta the world over. We do have good information on genetic adaptability. The forest sector has established extensive provenance trials, some of them shared with colleagues in the United States, for most of our commercial trees. These trials represent populations of trees that have been planted hundreds and even thousands of kilometers from their place of origin. Many trials are now 20-30 years old and constitute an invaluable store of information on adaptability under a wide range of conditions.

The Swedes did not select lodgepole pine to be their third most important species without first establishing that it is very adaptable (if somewhat susceptible to set winters). It would be prudent to assess the availability of our own genetic resources, in light of conditions that could develop over the next 50-100 years. Because, as one of the world's leading

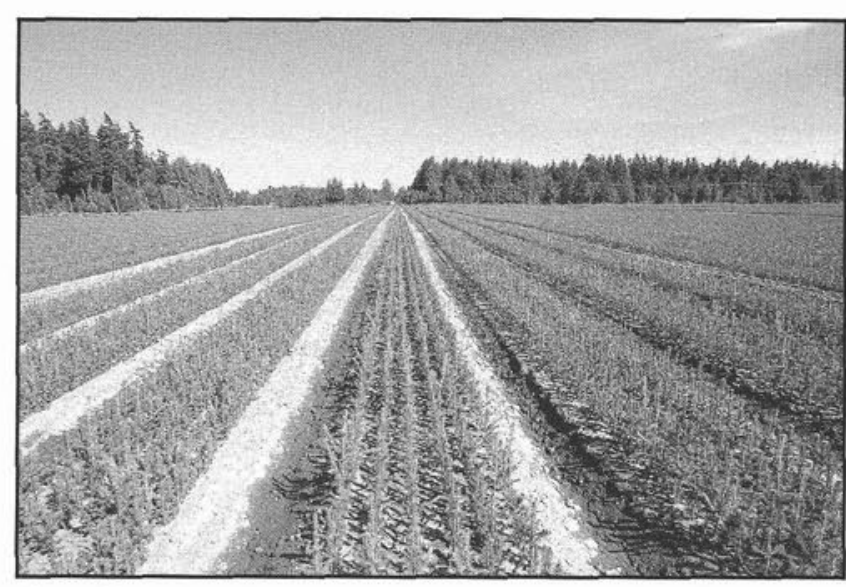

Figure 7. We have some capacity to accelerate migration of gene combinations to distant sites.

forest geneticists, Gene Namkoong of the US Forest Service, has pointed out, if we do not maintain adequate diversity there is a clear danger of losing the capacity to respond to large shifts in selection objectives (Namkoong 1990), and this is true whether these are to meet a changing climate or a new product opportunity.

There are some legitimate concerns about plantation forestry, but there are also some definite bonuses. One of the benefits of our high-tech forest lies in our ability to collect, store and deploy vast quantities of seed. British Columbia maintains a very large store of commercial tree seeds. The new provincial Seed Centre in Surrey, not far from here, currently has 45 tonnes of seed - 10 year's supply - and has the capacity to store 65 tonnes in long-term cold storage. There is a reasonable expectancy of long shelf life - in excess of 50 years - for seed of many of our commercial species. And there is an established capacity for moving planting stock over great distances. The larger nurseries in British Columbia, for example, each produce planting stock for all six regions of the province (British Columbia 1988b). This surely tells us something of the resilience of young seedlings to strange climates, when you consider that the Surrey nursery may be up to 10 degrees south of planting destinations. It also tells us we have some capacity to accelerate migration of gene combinations to distant sites.

To sum up on this point, there are in place procedures and infrastructures in the forest sector that can be brought to bear on the task of conserving and distributing genetic materials if needed. A systematic network of stands, managed as seed sources (Yeatman 1971), coupled with large-scale seed storage, would be an effective strategy to address the threat of diminished adaptiveness in our forest ecosystems. It could be augmented with a breeding program that could produce varieties selected for specific qualities such as drought resistance. The advantage of this strategy is that it is failsafe. If climate does not change, we shall not have compromised our forest. A comprehensive strategy of in situ and ex situ gene conservation will serve forestry well under any conditions, and should be in the sector's first line of defense for the future.

\section{Conclusion}

In conclusion, let me re-iterate the main points of this paper. First, climate change is but one of many uncertainties that foresters face, and is probably better researched than some. 


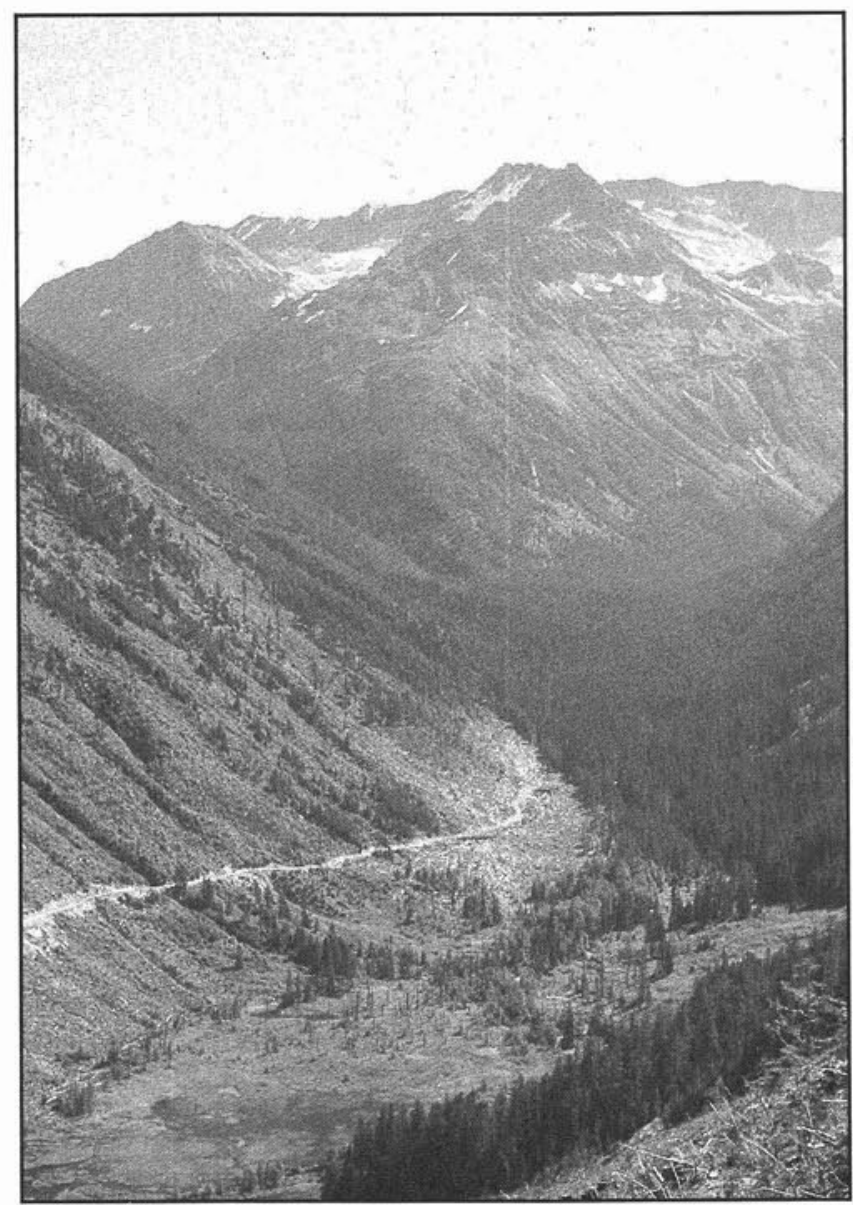

Figure 8. The predominant role of altitude in our landforms calls for strategies quite different from those elsewhere in Canada.

Second, the pressure for wise carbon management will continue to hound foresters. They should prepare themselves with sound quantitative information that will challenge the validity of ambitious and perhaps inappropriate schemes for storing carbon. Foresters may well find themselves on the positive side of the carbon balance. But they should also point to the great utility of trees that goes far beyond carbon storage.

Third, for a credible analysis of likely impacts of climate change, we need a new vision of the province, one that transforms our biogeoclimatic map to the year 2050 . We shall find that the predominant role of altitude in our landforms calls for strategies quite different from those elsewhere in Canada, where changes will occur over 100's of kilometers rather than 100's of meters.

Fourth, despite all uncertainties, we can develop what Buzz Holling and Ian Burton refer to as pre-adaptive, resilient strategies. The forest sector is adaptable by nature, but it has adapted mostly to a changing resource. This will remain important, but we must also prepare for a shift in the genetic resource. We have a good start on this task also.

Finally, let us remember that adaptation and mitigation deserve to be balanced with limitation. The future is not as bleak as Gary Larson once portrayed. We are not dinosaurs, and our brains are larger than walnuts. Let's use them.

\section{References}

Anonymous. 1989a. The major threats to the earth's environment. Time. Jan 2, pp. 54-55.
Anonymous. 1989b. The Noordwijk Declaration on Climate Change. Rep. of the Ministerial Conf. on Atmospheric Pollution and Climate Change, Noordwijjk, The Netherlands, Nov 6-7. Min. Housing, Phys. Plan. and Environ., Netherlands. 14 p.

Bonnor, G.M. 1985. Inventory of forest biomass in Canada. Can. For. Serv., Chalk River, Ont. Rep. 63 p.

Brandle, J. (In press). Shelterbelts: a buffer to climate on the Great Plains. In Proc. 1990 Canada/US Symp. Impacts of Climatic Change and Variability on the Great Plains. Calgary, Alberta, Sept. 10-13, 1990. Can. Clim. Cent., Downsview, Ont.

British Columbia. 1988a. Biogeoclimatic Zones of British Columbia. BC Min. Forest., Victoria, BC. Map.

British Columbia. 1988b. Annual Report. BC Min. Forests and Lands, Victoria, BC, pp. 61-62.

Burch, W.G. 1987. Future trends in the B.C. forest industry: moving beyond the myths. For. Chron. 63: 253-259.

Cooper, C.F. 1983. Carbon storage in managed forests. Can. J. For. Res. 13: 155-166.

Cowell, D. 1981. Loggers in winter. British Columbia Min. Forest. Forestalk 5: 3-8.

Harmon, M.E., W.K. Ferrell, and J.F. Franklin. 1990. Effects on carbon storage of conversion of old-growth forests to young forests. Science 247: 699-702.

Harper, J.L. 1990. Change in the global biological system. Invited lecture, Univ. British Columbia 1915-1990 Anniv. Conf., Global Environmental Change: the Implications for British Columbia, Vancouver, B.C., Sep 24-26 (unpub.).

Karl, T. (In press). Climate variability and change in the Great Plains during the instrumental period. In Proc. 1990 Canada/US Symp. Impacts of Climatic Change and Variability on the Great Plains. Calgary, Alberta, Sep 10-13. Can. Clim. Cent., Downsview, Ont.

Karlman, M. 1990. Gremmeniella infection on lodgepole pine in northern Sweden. Proc. Joint Mtg. West. Forest Genetics Assoc. and IUFRO Working Parties, Olympia, Wash. Aug 20-24. pp. 2.156-2.165.

Kurz, W.A., M.J. Apps, T.M. Webb, and P.J. McNamee. (In press). The contribution of biomass burning to the carbon budget of the Canadian forest sector: a conceptual model. In: Global biomass burning. J.S. Levine (ed.). Proc. Chapman Conf., Mar 19-23, 1990. Williamsburg, Virginia, MIT press.

Lavender, D.P., and S.G. Stafford. 1985. Douglas-fir seedlings: some factors affecting chilling requirement, bud activity, and new foliage production. Can. J. For. Res. 15: 309-312.

Levelton, B.H., and Associates. 1990. Carbon dioxide inventory for British Columbia. Crown Pub. Inc., Victoria, B.C. 95 p. + Appx.

Leverenz, J.W., and D.J. Lev. 1987. Effects of carbon dioxideinduced climate changes on the natural ranges of six major commercial tree species in the western United States. In: The greenhouse effect, climate change, and U.S. forests. W.E. Shands and J.S. Hoffman (Eds.) Conservation Foundation, Washington, D.C. pp. 123-155.

Namkoong, G. 1990. Forest genetics, 2050: the quick and the dead. Proc. Joint Mtg. West. Forest Genetics Assoc. and IUFRO Working Parties, Olympia, Wash. Aug. 1990.

Neftel, A., E. Moor, H. Oeschger, and B. Stauffer. 1985. Evidence from polar ice cores for the increase in atmospheric $\mathrm{CO} 2$ in the last two centuries. Nature 315: 45-47.

Pelkonen, P. 1990. Response strategies of boreal forests. Univ. Joensuu, Finland. Unpub. Rep. 7 p.

Pollard, D.F.W. 1985. A forestry perspective on the carbon dioxide issue. For. Chron. 61: 312-318.

Rizzo, B. 1988. The sensitivity of Canada's ecosystems to climate change. Can. Comm. Ecol. Land Classification Newsletter 17: $10-12$.

Yeatman C.W. 1971. Gene conservation in relation to forestry practice. Proc. 13th Meet. Comm. Forest Tree Breeding in Canada, Prince George, B.C. Aug 24-27, Part 2, pp. 19-24. 